\title{
Characterisation of lipids in okra mature seeds
}

\author{
Edith Adouko AGBO ${ }^{1 *}$, Jean GNOPO NEMLIN ${ }^{2}$, Blanchard KOUTOUA ANVOH ${ }^{1}$ and \\ Dago GNAKRI ${ }^{1}$ \\ ${ }^{1}$ Food Sciences and Technology Department, Abobo-Adjamé University, 02 P.O. Box 801 Abidjan 02, Côte \\ d'Ivoire. \\ ${ }^{2}$ National Agricultural Research Centre (CNRA), 08 P.O. Box 33 Abidjan 08, Côte d'Ivoire. \\ *Corresponding author, E-mail: ceapadouko@yahoo.fr, Tel: (225) 077903 64, Fax: (225) 22442108
}

\begin{abstract}
The seeds of six okra varieties namely Tomi, GB2/04Ab, GB9/04La, GB4/04BB, GB8/04KB and Indiana were analysed for their oil content during fruits maturation. Mature seeds of this vegetable were characterized for their masses, density, physical properties and composition of lipids. The results indicated that lipids increased with maturation process. $G B 2 / 04 A b$ variety had the most elevated lipid level at maturity (22.55 $\pm 0.15 \%)$ and $G B 4 / 04 B B$ the least elevated one $(13.52 \pm 0.08 \%)$. Mature seeds had a high density. The iodine value increased from $52.67 \pm 1.25 \mathrm{mg} \mathrm{I}_{2} / 100 \mathrm{~g}$ (Tomi) to $102.17 \pm 0.49 \mathrm{mg} \mathrm{I}_{2} / 100 \mathrm{~g}$ (Indiana). GB2/04Ab had the lowest peroxide value of $2.16 \pm 1.92 \mathrm{meq} \mathrm{O}_{2} / \mathrm{kg}$ and Indiana, the lowest saponification value $(137.7 \pm 2.75$ $\mathrm{mg} / \mathrm{g}$ ). The fatty acids identified were capric, lauric, palmitic, myristoleic, stearic, oleic, linoleic and behenic acids. However, saturated fatty acids proportion was more important than unsaturated one varying respectively from $58.07 \%$ to $70.96 \%$ and from $29.04 \%$ to $41.93 \%$. Therefore, okra mature seeds oil is stable to autoxidation. (C) 2010 International Formulae Group. All rights reserved.
\end{abstract}

Keywords: Vegetable, okra, varieties, maturation process, stable oil, fatty acids.

\section{INTRODUCTION}

Okra is a vegetable largely consumed in WestAfrica. In Côte d'Ivoire, the production is around 115.867 tons (Anonyme 2009). Two okra species Abelmoschus esculentus (L.) Moench (common okra) and Abelmoschus caillei (A. Chev.) Stevels (West African okra) are cultivated and consumed throughout the year. Okra is primarily grown for its immature pods which are consumed when cooked either alone or in combination with other vegetables (eggplants, tomatoes, onions). Okra fruits provide minerals, vitamins and proteins (Agbo et al., 2008).
However, several studies have reported that okra is also useful for its seeds. Indeed, in Turkey, the seeds of mature okra are roasted, ground and used as a coffee substitute (Çalişir et al., 2005). The seed powder has also been used as a substitute for aluminium salts in water purification (Camciuc et al., 1998). Moreover, okra seeds are a good source of protein and oil. The protein content of okra seed is as high as $45 \%$ after extraction of oil (Oyenuga 1968) and the oil appears to be as good as cottonseed oil (Aminigo and Akingbala 2004). According to Savello et al. (1980), okra seed oil is rich in unsaturated 
fatty acids such as linoleic acid which is essential for human nutrition. Although the oil of okra seeds is inherently edible, the seeds are not being processed for oil in Côte d'Ivoire but only for seedling and regeneration purposes. However, okra fruits are consumed with their seeds in fresh or dried form. This study was carried out to evaluate the level of lipids in okra seeds at different maturity stages and to determine the composition of the oil extracted.

\section{MATERIALS AND METHODS}

\section{Sampling procedure}

Six okra varieties were used for this study: Tomi, GB2/04Ab, GB9/04La, $G B 4 / 04 B B, G B 8 / 04 K B$ and Indiana. They were cultivated at the experimental station of the National Agricultural Research Centre (CNRA) at Anguédédou (5.5 North Latitude and $5.5^{\circ}$ West Longitude). The crops were arranged in a randomized complete blocks design with 3 repetitions. Seeds were sown in October 2004 and in September 2005 in a soil fertilized with 10-18-18 NPK (250 kg/ha) and plots were irrigated when necessary. Harvests began on average 90 days after sowing. As fruits appear after flowering, the first day of fruits growth was determined at this moment. So, on the crops, fruits were identified and picked according to the age requested $(3,5,7$, 9 and 11 days). For the experiment, two kinds of sample were taken into account. Firstly, seeds of fresh okra fruits aged of 3, 5, 7, 9 and 11 days and secondly, seeds of dried pods of 45 days. For the analysis, fresh seeds were dried in an oven (Selecta Memmert, Germany) at $45{ }^{\circ} \mathrm{C} \pm 2{ }^{\circ} \mathrm{C}$ for $24-36$ hours. The mature seeds were also kept in an oven at $45{ }^{\circ} \mathrm{C} \pm 2$ ${ }^{\circ} \mathrm{C}$. Both kinds of seeds were powdered using an electronic DCFH 48 grinder (Stanmore, England) to pass through a 1.5 - mesh. All samples were stored in airtight containers. Before grinding, the mass of 100 dried mature seeds was determined on an electronic balance (Sartorius AG, BP 310S, Germany) to an accuracy of $0.001 \mathrm{~g}$. The density of 100 dried mature seeds was also determined by immersing the seeds in water and removing those that floated. The latter were considered as light seeds. Seeds that sank were then immersed in a $20 \%$ sucrose solution. Seeds that floated were considered of medium density and seeds that sank were classified as denser.

\section{Analysis}

Lipids were extracted with hexane using a Soxhlet apparatus (Soxtherm automatic Gerhardt SE 3M, Ahrensburg, Denmark) during 6 hours. After extraction of lipids solvent was evaporated on a rotavapor at $45{ }^{\circ} \mathrm{C}$. Lipids of dried mature seeds were subject to the determination of acid value, iodine value, peroxide value and saponification value according to AOAC (2005) respectively \# 969.17, \# 993.20, \# 965.33 and \# 920.160 methods. The fatty acid composition of the oil was also determined by gas chromatography (Camciuc et al., 1998). The oils were converted to methyl esters by treatment firstly with $1 \mathrm{~N} \mathrm{NaOH}$, for 2 min at $60{ }^{\circ} \mathrm{C}$ in Soxhlet apparatus. Then, sulphuric acid $(20 \%, \mathrm{v} / \mathrm{v})$ was added slowly and the solution reheated until becoming translucent. Finally, a solution of methanol - sulphuric acid (10:90, v/v) was added to the translucent solution and the mixture was brought to the boil for 2 hours. For dosage, $1 \mu$ l of methyl esters solution was injected into a Hewlett Packard 6890 series Gas Chromatograph system equipped with flame ionization detector under the following conditions: HP 5 capillary column (Cross-linked 5\% PH ME Siloxane, $0.32 \mathrm{~mm}$ i. d. $x 30 \mathrm{~m}$ ), azote pressure used as vector gas (from 6.9 to 47.6 $\mathrm{kPa}$ ) and carrier gas flow (hydrogen) at 1 $\mathrm{cm}^{3} / \mathrm{min}$. The oven temperature was varying from $-60{ }^{\circ} \mathrm{C}$ to $+325{ }^{\circ} \mathrm{C}$. The injection port temperature was at $275{ }^{\circ} \mathrm{C}$ and the detector temperature at $325{ }^{\circ} \mathrm{C}$. Fatty acid esters were identified by comparing their retention time with those of known reference compounds. 


\section{Statistical analysis}

Results were expressed as mean \pm standard deviation of the triplicate assays. Data were analyzed using STATISTICA $99^{\text {th }}$ edition (Oklahoma, USA). A one-way analysis of variance (ANOVA) was performed and means were separated using a Duncan multiple range test $\quad(p=0.05)$.

\section{RESULTS}

Lipids content of fresh okra seeds according to maturity stage

Lipids levels in the okra seeds increased consistently during fruits maturation (Table 1). Seeds of GB4/04BB variety contained the lowest lipids concentration which varied from $1.56 \pm 0.06 \%$ at 3 days to $10.44 \pm 0.14 \%$ at 11 days. For the others varieties, the lipids levels ranged, from $3^{\text {rd }}$ to $11^{\text {th }}$ days, between $2.5 \pm 0.1 \%$ and $11.42 \pm$ $0.22 \%$ for $G B 9 / 04 L a$, between $2.69 \pm 0.09 \%$ and $12.28 \pm 0.28 \%$ for Tomi and between 3.06 $\pm 0.06 \%$ and $12 \pm 0.6 \%$ for Indiana. For $G B 8 / 04 K B$ and $G B 2 / 04 A b$ the variations were respectively from $3.73 \pm 0.03 \%$ to $12.29 \pm$ $0.09 \%$ and from $3.80 \pm 0.01 \%$ to $11.9 \pm 0.4 \%$. There was a significant difference between the different maturation levels of Tomi, $G B 2 / 04 A b, \quad G B 9 / 04 L a, \quad G B 4 / 04 B B$ and $G B 8 / 04 K B$ ( $\mathrm{p}<0.05)$. But, for Indiana variety, there was no significant difference of lipids concentration between the $5^{\text {th }}$ and the $7^{\text {th }}$ day, on the one hand and between the $9^{\text {th }}$ and the $11^{\text {th }}$ day, on the other hand. Furthermore, varieties comparison at each maturation level revealed that, at $3^{\text {rd }}$ day, there was no significant difference between lipids level of $G B 8 / 04 K B$ and $G B 2 / 04 A b$ which had the most elevated value. At $5^{\text {th }}$ and $9^{\text {th }}$ days, lipids concentration of Tomi and GB9/04La were similar, but, they differed significantly to the other varieties. At $7^{\text {th }}$ day, there was no significant difference between Indiana and $G B 2 / 04 A b$ on the one hand and between Tomi, $G B 9 / 04 L a$ and $G B 8 / 04 K B$ on the other hand. At $11^{\text {th }}$ day, there was no significant difference between lipids level of Tomi,
$G B 2 / 04 A b, G B 8 / 04 K B$ and Indiana ( $>$ > 0.05). The potential of seeds in lipids content during maturation urge us to analyse okra mature seeds.

\section{Physical properties of mature okra seeds}

The average masses of hundred seeds ranged from $4.7 \pm 0.12 \mathrm{~g}(G B 2 / 04 A b)$ to 7.38 $\pm 0.09 \mathrm{~g}$ (Indiana) (Table 2). However, masses of Abelmoschus caillei (Tomi, $G B 2 / 04 A b, G B 9 / 04 L a$ ) varieties seeds were the lowest compared to those of Abelmoschus esculentus (GB4/04BB, GB8/04KB, Indiana) varieties. Seeds density of $G B 2 / 04 A b$, as well as that of Tomi, $G B 4 / 04 B B$ and $G B 8 / 04 K B$ was higher than that of Indiana. Indeed, respectively $73 \%, 79 \%, 83 \%$ and $91 \%$ of $G B 2 / 04 A b$, Tomi, GB4/04BB and GB8/04KB seeds have a high density against $12 \%$ of Indiana seeds (Figure 1). There was a significant difference between all varieties for seeds which had high density. For the medium density, seeds of Tomi, $G B 4 / 04 B B$ and $G B 8 / 04 K B$ differed to seeds of $G B 2 / 04 A b$ and GB9/04La which also differed to that of Indiana. The most elevated percentage of low density seeds was observed in Indiana and it differed significantly to the other varieties ( $\mathrm{p}$ $<0.05)$. So, it seems that the density of commercial variety seeds (Indiana) was lower than that of local varieties.

\section{Characteristic of lipids in okra mature seeds}

There were significant differences between lipids levels of okra mature seeds ( $\mathrm{p}$ $<0.05$ ). At maturity, seeds provided more lipids than during maturation process. Lipids levels of A. esculentus varieties (13.52 \pm $0.08 \%$ for $G B 4 / 04 B B, 14.61 \pm 0.09 \%$ for $G B 8 / 04 K B$ and $15.57 \pm 0.07 \%$ for Indiana) were lower than those of $A$. caillei varieties $(15.79 \pm 0.19 \%$ for $G B 9 / 04 L a, 16.74 \pm 0.06 \%$ for Tomi and $22.55 \pm 0.15$ for $G B 2 / 04 A b$ ) (Figure 2).

The lipids recovered from the seeds of the six okra varieties were examined for their 
Table 1: Lipids level in okra seeds at diverse maturity stage.

\begin{tabular}{lccccc}
\hline \multicolumn{5}{c}{ Lipids (\%) } \\
\hline Days & 3 & 5 & 7 & 9 & 11 \\
\hline Tomi & & & & \\
\hline GB2/04Ab & $2.69^{\mathrm{c}} \pm 0.09$ & $5.03^{\mathrm{b}} \pm 0.03$ & $7.89^{\mathrm{b}} \pm 0.19$ & $9.17^{\mathrm{bc}} \pm 0.17$ & $12.28^{\mathrm{c}} \pm 0.28$ \\
\hline GB9/04La & $3.80^{\mathrm{e}} \pm 0.01$ & $7.68^{\mathrm{d}} \pm 0.68$ & $9.00^{\mathrm{c}} \pm 0.6$ & $10.64^{\mathrm{d}} \pm 0.54$ & $11.90^{\mathrm{c}} \pm 0.4$ \\
\hline GB4/04BB & $2.50^{\mathrm{b}} \pm 0.1$ & $5.08^{\mathrm{b}} \pm 0.08$ & $7.82^{\mathrm{b}} \pm 0.32$ & $8.67^{\mathrm{b}} \pm 0.37$ & $11.42^{\mathrm{b}} \pm 0.22$ \\
\hline GB8/04KB & $1.56^{\mathrm{a}} \pm 0.06$ & $3.41^{\mathrm{a}} \pm 0.11$ & $4.64^{\mathrm{a}} \pm 0.3$ & $6.02^{\mathrm{a}} \pm 0.06$ & $10.44^{\mathrm{a}} \pm 0.14$ \\
\hline Indiana & $3.73^{\mathrm{e}} \pm 0.03$ & $5.97^{\mathrm{c}} \pm 0.03$ & $7.34^{\mathrm{b}} \pm 0.12$ & $9.54^{\mathrm{c}} \pm 0.34$ & $12.29^{\mathrm{c}} \pm 0.09$ \\
\hline & $3.06^{\mathrm{d}} \pm 0.06$ & $8.82^{\mathrm{e}} \pm 0.32$ & $8.93^{\mathrm{c}} \pm 0.53$ & $11.60^{\mathrm{e}} \pm 0.3$ & $12.00^{\mathrm{c}} \pm 0.6$ \\
\hline
\end{tabular}

In a row, means values followed by different superscript are statistically different $(\mathrm{p} \leq 0.05)$ (Duncan test).

Table 2: Weight of 100 mature seeds.

\section{Tomi GB2/04 Ab GB9/04La GB4/04 BB GB8/04KB Indiana}

\begin{tabular}{|c|c|c|c|c|c|c|}
\hline & $5.17^{b}$ & $4.70^{\mathrm{a}}$ & $5.58^{\mathrm{c}}$ & $5.59^{c}$ & $6.06^{\mathrm{d}}$ & $7.38^{\mathrm{e}}$ \\
\hline Weight (g) & \pm 0.09 & \pm 0.12 & \pm 0.11 & \pm 0.31 & \pm 0.14 & +0.09 \\
\hline
\end{tabular}

In line, means values followed by different superscript are statistically different $(\mathrm{p} \leq 0.05)$ (Duncan test).

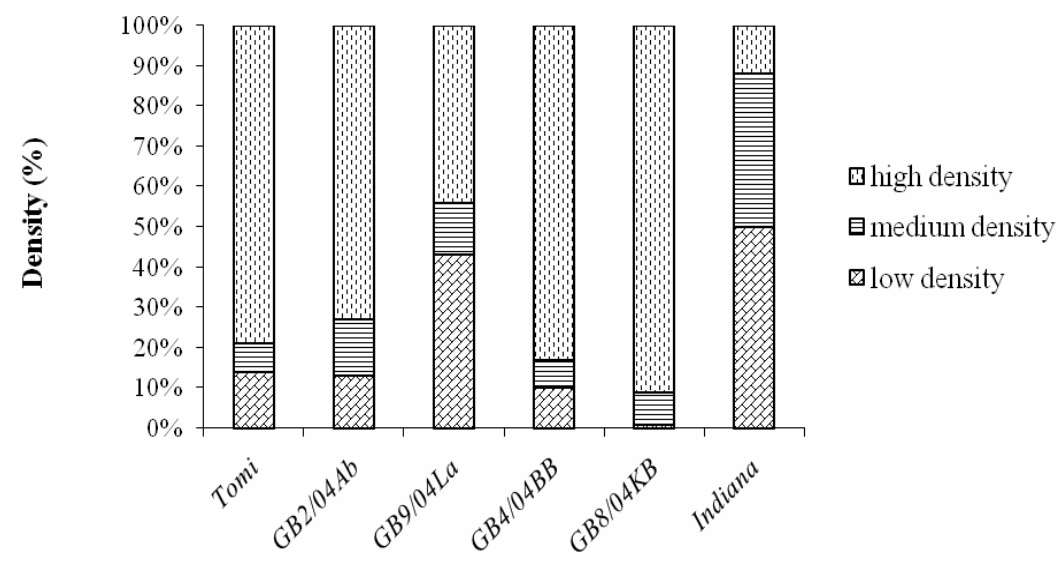

Varieties

Figure 1: Density of hundred okra seeds. 


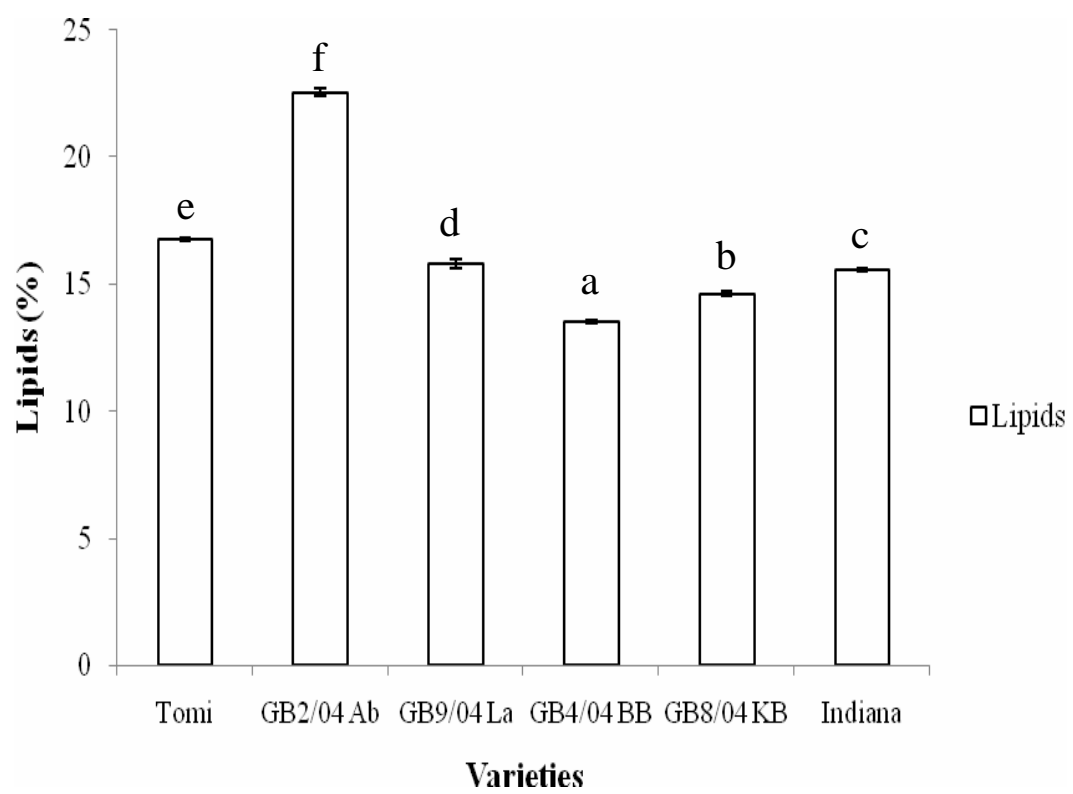

Figure 2: Lipids level of okra mature seeds.

physical constants and other characteristics (Table 3). GB2/04Ab seeds oil has the highest acid value $(125.43 \pm 4.18 \mathrm{~g} / 100 \mathrm{~g})$ and Indiana, the lowest one $(11.44 \pm 4.04 \mathrm{~g} / 100$ g). However, results from the acid value showed no significant difference between GB8/04KB, Indiana and Tomi ( $\mathrm{p}>0.05$ ). The Indiana sample had the highest iodine value $\left(102.17 \pm 0.49 \mathrm{mg} \mathrm{I}_{2} / 100 \mathrm{~g}\right)$, as compared to those of $G B 9 / 04 \mathrm{La}\left(95.24 \pm 1.56 \mathrm{mg} \mathrm{I}_{2} / 100\right.$ $\mathrm{g}), G B 8 / 04 K B\left(94.6 \pm 0.92 \mathrm{mg} \mathrm{I}_{2} / 100 \mathrm{~g}\right)$ and

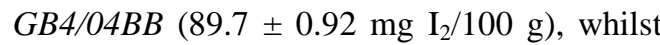
those of Tomi $\left(52.67 \pm 1.25 \mathrm{mg} \mathrm{I}_{2} / 100 \mathrm{~g}\right)$ and $G B 2 / 04 A b\left(59.5 \pm 1.35 \mathrm{mg} \mathrm{I}_{2} / 100 \mathrm{~g}\right)$ had the minimum iodine values. In addition, $G B 2 / 04 A b$ had the lowest peroxide value of $2.16 \pm 1.92 \mathrm{meq}_{2} / \mathrm{kg}$ and Indiana, the lowest saponification value $(137.7 \pm 2.75 \mathrm{mg} / \mathrm{g})$.

The fatty acids composition of okra mature seeds were identified and shown (Figure 3$)$. Nine of them were detected in $G B 8 / 04 K B, \quad G B 4 / 04 B B, \quad G B 2 / 04 A b$ and Indiana against seven in Tomi and GB9/04La.
The fatty acids detected in all varieties were palmitic acid, stearic acid, oleic acid and linoleic acid. Besides the common fatty acids, capric acid, lauric acid and myristoleic acid were also identified. Behenic acid was identified only in $G B 8 / 04 K B$. Palmitic acid is the major saturated fatty acid and among the unsaturated fatty acids, oleic acid was higher than linoleic acid. Moreover, in okra mature seeds lipid, there were more saturated fatty acids than unsaturated one, varying respectively from $58.07 \%$ to $70.96 \%$ and from $29.04 \%$ to $41.93 \%$. The ratio of linoleic acid to oleic acid goes from 0.12 to 0.17 (Table 4).

\section{DISCUSSION}

The increasing of lipids level with maturation of the okra seeds could be due to growth factors. In small fruits, they favour mucilage, sugars and proteins accumulation (Camciuc et al., 1998). But, with ripening, there is a loss of these nutrients and an activation of lipids synthesis which is 
Table 3: Indices value of okra mature seeds lipids.

\begin{tabular}{|c|c|c|c|c|}
\hline & $\begin{array}{l}\text { Acid value } \\
\text { (g/100 g) }\end{array}$ & $\begin{array}{l}\text { Iodine value } \\
\left(\mathbf{m g ~} \mathrm{I}_{2} / 100 \mathrm{~g}\right)\end{array}$ & $\begin{array}{l}\text { Peroxide value } \\
\left(\text { meq } \mathrm{O}_{2} / \mathrm{kg}\right)\end{array}$ & $\begin{array}{c}\text { Saponification } \\
\text { value (mg/g) }\end{array}$ \\
\hline Tomi & $17.34^{\mathrm{a}} \pm 1.84$ & $52.67^{\mathrm{a}} \pm 1.25$ & $36.57^{c} \pm 4.47$ & $228.77^{\mathrm{c}} \pm 2.04$ \\
\hline$G B 2 / 04 A b$ & $125.43^{\mathrm{d}} \pm 4.18$ & $59.50^{b} \pm 1.35$ & $2.16^{\mathrm{a}} \pm 1.92$ & $211.33^{b} \pm 2.91$ \\
\hline GB9/04La & $38.65^{b} \pm 2.76$ & $95.24^{\mathrm{d}} \pm 1.56$ & $31.33^{\mathrm{c}} \pm 4.81$ & $206.73^{b} \pm 5.66$ \\
\hline$G B 4 / 04 B B$ & $54.20^{c} \pm 4.22$ & $89.70^{c} \pm 0.92$ & $19.53^{b} \pm 1.84$ & $209.30^{b} \pm 4.12$ \\
\hline$G B 8 / 04 K B$ & $13.21^{\mathrm{a}} \pm 2.65$ & $94.60^{\mathrm{d}} \pm 0.92$ & $65.93^{\mathrm{e}} \pm 2.91$ & $224.00^{c} \pm 2.86$ \\
\hline Indiana & $11.44^{\mathrm{a}} \pm 4.04$ & $102.17^{\mathrm{e}} \pm 0.49$ & $47.90^{\mathrm{d}} \pm 3.05$ & $137.70^{\mathrm{a}} \pm 2,75$ \\
\hline
\end{tabular}

In a row, means values followed by different superscript are statistically different ( $\mathrm{p} \leq 0.05)$ (Duncan test).

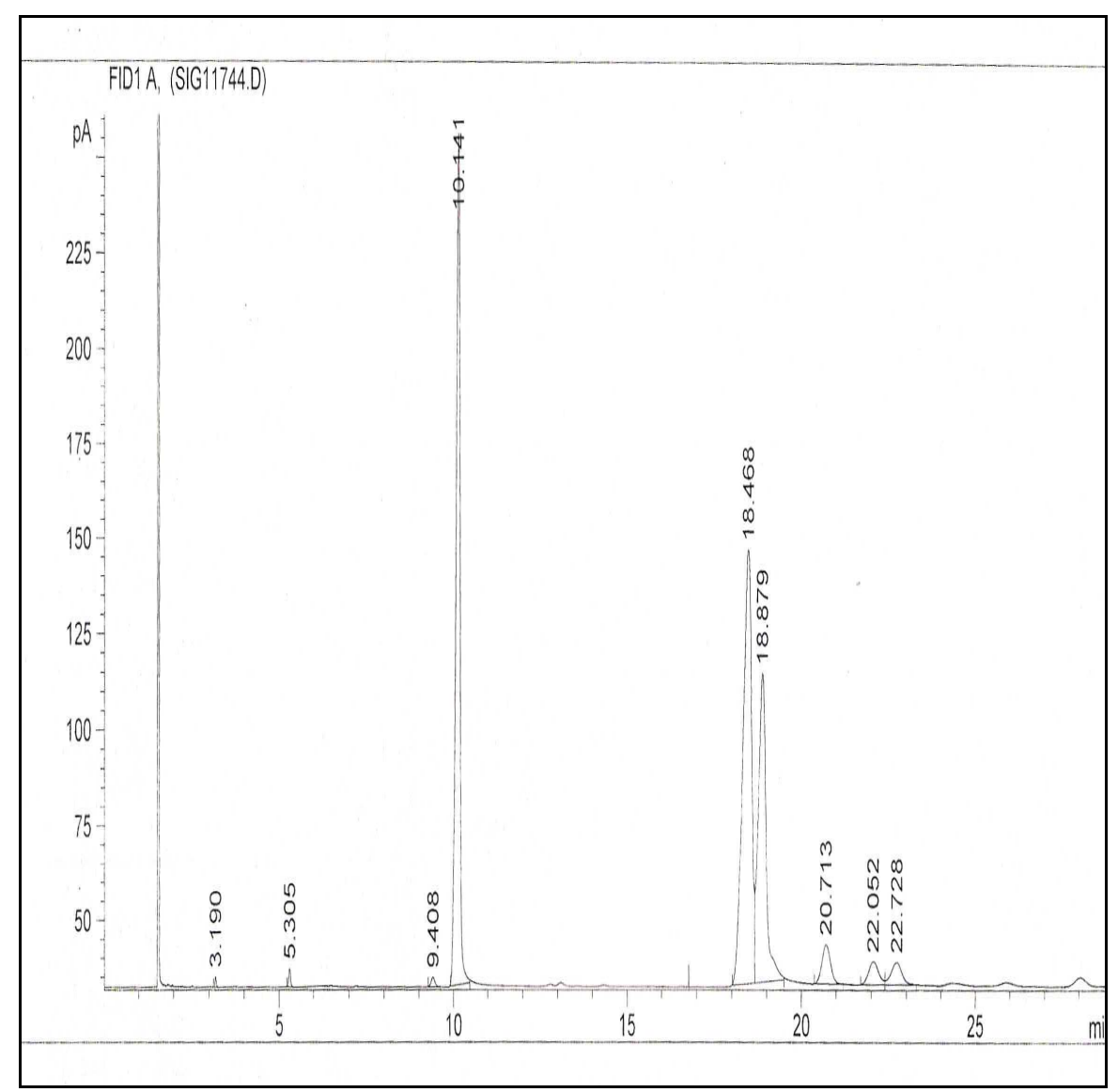

Figure 3: Fatty acids chromatogram of Indiana seeds lipids.

1: C10:0 (capric acid), 2: C12:0 (lauric acid), 3: C14:1 (myristoleic acid), 4: C16:0 (palmitic acid), 5: C18:0 (stéaric acid), 6: C18:1 (oleic acid), 7: C18:2 (linoleic acid), 8: C20:0 (arachidic acid), 9: C20:1 (gadoleic acid) 
Table 4: Fatty acids composition of lipids.

\begin{tabular}{|c|c|c|c|c|c|c|}
\hline & \multicolumn{6}{|c|}{ Fatty acids (\%) } \\
\hline & Tomi & $G B 8 / 04 K B$ & $G B 4 / 04 B B$ & GB9/04La & $G B 2 / 04 A b$ & Indiana \\
\hline C10:0 & 0.08 & - & 0.07 & - & 0.31 & 0.10 \\
\hline C12:0 & 0.40 & 0.46 & 0.34 & 0.22 & 0.38 & 0.32 \\
\hline C16:0 & 31.55 & 32.09 & 30.89 & 29.54 & 33.06 & 32.77 \\
\hline C18:0 & 36.22 & 21.03 & 26.33 & 25.39 & 28.46 & 35.56 \\
\hline C20:0 & - & 4.29 & 2.09 & 2.92 & 2.91 & 2.21 \\
\hline C22:0 & - & 1.99 & - & - & - & - \\
\hline $\begin{array}{l}\text { Total } \\
\text { SFA }\end{array}$ & 68.25 & 59.86 & 59.72 & 58.07 & 65.12 & 70.96 \\
\hline C14:1 & 0.48 & 0.41 & 0.32 & - & 0.44 & 0.36 \\
\hline C18:1 & 27.97 & 30.44 & 32.88 & 34.74 & 26.64 & 23.11 \\
\hline C18:2 & 3.30 & 4.94 & 4.84 & 4.08 & 4.50 & 3.20 \\
\hline C20:1 & - & 4.35 & 2.24 & 3.11 & 3.30 & 2.37 \\
\hline $\begin{array}{l}\text { Total } \\
\text { UFA }\end{array}$ & 31.75 & 40.14 & 40.28 & 41.93 & 34.88 & 29.04 \\
\hline $\begin{array}{l}\text { C18:2 / } \\
\text { C18:1 }\end{array}$ & 0.12 & 0.16 & 0.15 & 0.12 & 0.17 & 0.14 \\
\hline
\end{tabular}

SFA: Saturated fatty acids

UFA: Unsaturated fatty acids

implicated in seeds formation (Longe et al., 1982). Moreover, Balasubramanian and Sadasivan (1987) have showed that lipids accumulation begins from $7^{\text {th }}$ maturity day $(0.4 \%)$ to $42^{\text {nd }}$ day $(15.6 \%)$.

The difference of masses between $A$. caillei varieties and $A$. esculentus varieties was also revealed by Martin et al. (1983) who indicated a mean weight of $5.2 \mathrm{~g}$ for $A$. caillei and $6.4 \mathrm{~g}$ for $A$. esculentus. Lipids properties analysis showed that iodine values of our studied varieties were relatively lower than those indicated by Pham et al. (2003) instead of peroxide value of oil which was generally high. But, a lower peroxide value was an indicator for a best quality of the oil.

Palmitic acid level of $G B 8 / 04 K B$ and Indiana were similar to that indicated by Pham et al. (2003) to be $32.23 \%$. But linoleic acid level was less important than that 
reported by the same authors. Okra mature seeds oil could be characterized by its high degree of saturated fatty acids which make it stable oil against autoxidation. This was confirmed by the fact that iodine value and linoleic acid to oleic acid ratio were low because of the low degree of unsaturation (Sujatha et al., 1986). However, this result was in contradiction with that of Berry et al. (1988). So, okra mature seeds lipid is stable and the high proportion of saturated acid, particularly palmitic acid, is greatest to improve the quality of some oils, such as soybean oil, which has limitations as a shortening as it only contains around 11\% palmitic acid (Camciuc et al., 1998).

\section{Conclusion}

This study revealed that lipids increased with fruits maturation. In general, okra mature seeds have a high density and provide an important oil percentage, and the levels are for a green vegetable. However, this oil is characterized by its saturated fatty acids which were found to be higher in the seeds than the unsaturated. So, okra seeds lipids could not be processed for use as oil like grape seeds oil. Although okra mature seeds oil contains a less proportion of essential fatty acids, it is stable, could contribute to human metabolism and the fatty acids identified are useful for the fruit growth.

\section{REFERENCES}

AOAC. 2005. Official Method of Analysis of AOAC International. \# 969.17: Acid value, chp 33, 64-65. \# 993.20: Iodine value of fats and oil, Wijs method, chp 41, 7. \# 965.33: Peroxide value method, chp 41, 11-12. \# 920.160: Saponification number, Chp 41, p 12. $18^{\text {th }}$ Edition. AOAC.

Agbo AE, Gnakri D, Beugré GM, Fondio L, Kouamé C. 2008. Maturity degree of four okra fruits varieties and their nutrients composition. Electronic Journal of Foods and Plants Chemistry., 3(1): $1-4$.

Aminigo ER, Akingbala JO. 2004. Nutritive composition and sensory properties of Ogi Fortified with Okra Seed meal. J. Appl. Sci. Environ. Mgt., 8(2): 23 - 28.

Anonyme. 2009. Concertation régionale sur la situation alimentaire et nutritionnelle au Sahel et en Afrique de l'Ouest, Cotonou/ Bénin. Ministère de l'Agriculture, Campagne Agricole, Rapport 2008/2009, Côte d'Ivoire, p. 21.

Balasubramanian T, Sadasiv AMT. 1987. Changes in starch, oil, protein and amino acids in developing seeds of okra (Abelmoschus esculentus (L.) Moench). Plant Foods for Human Nutrition., 37: 41- 46.

Berry SK, Kalra CL, Sehgal RC, Kulkarni SG, Kour S, Arora SK, Sharma BR. 1988. Quality characteristics of seeds of five okra (Abelmoschus esculentus L.) cultivars. J. Fd. Sci. Techno., 25(5): 303 305.

Çalişir S, Özcan M, Haciseferoğullari $\mathrm{H}$, Yildiz UM. 2005. A Study on some physic-chemical properties of Turkey okra (Hibiscus esculenta L.) seeds. Journal of Food Engineering, 68: 73-78.

Camciuc M, Deplagne M, Vilarem G, Gaset A. 1998. Okra - Abelmoschus esculentus (L.) Moench, a crop with economic potential for set aside acreage in France. Industrial Crops of Products, 7(2-3): 257- 264.

Longe OG, Fetuga BL, Aken'ova ME. 1982. Changes in the composition and carbohydrate constituents of okra (Abelmoschus esculentus L.) with age. Food Chemistry., 8: 27 - 32.

Martin FW, Rhodes AM. 1983. Seed characteristics of okra and related Abelmoschus species. Qual. Plant. Plant Foods Hum. Nutr., 33: 41 - 49. 
Oyenuga VA. 1968. Nigerian Foods and Feedingstuff: Their Chemistry and Nutritive Value ( $3^{\text {rd }}$ edn). Ibadan University Press: Nigeria; 90.

Pham PJ, Peralta MM, Pham LJ. 2003. Okra (Hibiscus esculentus L.) seed oil: characterization and potential use for high value products. In Advanced Research on Plants Lipids, Murata N, Yamada M, Nishida I, Okuyama H, Sekiya J, Hajime W (eds). Kluwer Academic Publishers: Netherland; $35-38$.
Savello PA, Martin FW, Hull JM. 1980. Nutrient composition of Okra seed meals. J. Agric. Food Chem., 28: 1163 - 1166.

Sujatha VS, Madaan TR, Seshadri VS. 1986. Oil content and its quality in seeds of wild and cultivated species of Abelmoschus. Indian Journal of Agriculture Sciences, 56(9): 657 - 660. 